Research Article

\title{
Optimization of Cultural and Physical Parameters for Phenol Biodegradation by Newly Identified Pseudomonas sp. AQ5-04
}

\author{
Abubakar Aisami ${ }^{1 *}$, Nur Adeela Yasid ${ }^{2}$, Mohd Yunus Abd Shukor ${ }^{2}$ \\ ${ }^{1}$ Department of Biochemistry, Faculty of Sciences, Gombe State University, Gombe, Nigeria \\ ${ }^{2}$ Department of Biochemistry, Faculty of Biotechnology and Bimolecular Sciences, Universiti Putra Malaysia, Serdang 43400, \\ Malaysia
}

Article history:

Submission February 2020

Revised May 2020

Accepted May 2020

*Corresponding author:

E-mail:

abubakar.aisami05@gmail.com

\begin{abstract}
Phenol is widely used by many industries and it is one of the highly toxic environmental pollutants. Bioremoval is one of the most effective methods to remove phenol compared to other physio-chemical methods. Identification was carried out using 16s rRNA sequencing. Mineral salt media with $0.5 \mathrm{~g} / \mathrm{L}$ phenol as the sole source of carbon. Factors influencing phenol degradation were optimised via onefactor-at-a-time and response surface methodology. Optimum degradation was achieved at $\mathrm{pH} 7.5$, the temperature of $30^{\circ} \mathrm{C}$ and ammonium sulphate at $0.4 \mathrm{~g} / \mathrm{L}$. Using Response surface methodology the incubation period was reduced to $36 \mathrm{~h}$ compared to the OFAT approach where it takes 72 hours. The effect of 10 heavy metals at various concentrations was tested. The optimum values used for temperature, $\mathrm{pH}$, ammonium sulphate and salinity for both the OFAT and RSM have correlated with the only $\mathrm{pH}$ displayed the slighted difference of 7.0 for OFAT and 7.5 for RSM. This shows the closest optimum conditions for both methods. The strain is also resistance to some heavy metals usually found in polluted environments together with phenol. Therefore, it can be clearly stated that Pseudomonas sp. strain AQ5-04 is the potential candidate for phenol bioremediation and further studies in the field of bioremediation. The bacterium can degrade phenol in the presence of between 1 to $3 \mathrm{ppm}$ of the heavy metals As, Cd, Co, and $\mathrm{Zn}$ while growth and degradation were inhibited by $\mathrm{Hg}, \mathrm{Ag}, \mathrm{Cu}$ and $\mathrm{Ni}$ at $1 \mathrm{ppm}$. The isolate is a potential strain for further bioremediation studies.
\end{abstract}

Keywords: Phenol-degrading, Pseudomonas sp., Response surface methodology heavy metals, One factor at a time

\section{Introduction}

Phenols and phenolic compounds are poisonous to organisms even at low concentrations, with many of them are categorized as dangerous pollutants due to their toxicity towards human health for various reasons [1]. Some of the phenolic compounds include chlorophenols, nitrophenols, methyl phenols, alkylphenol, aminophenol, butylhydroxytoluene, nonylphenol and bisphenols A [1]. In Malaysia, the 2014 Environmental Quality Report showed that nearly all groundwater monitoring stations had phenol concentrations exceeding the National Guidelines for Drinking Water Quality Standard $(0.002 \mathrm{mg} / \mathrm{L})$. Phenol and phenolic compounds continue to be the top scheduled wastes generated in Malaysia as the demand for phenol by the industries are increasing annually [3].

There are various physicochemical methods for the removal of phenol pollution from the environment, such as polymerisation [4], electrocoagulation [5] photodecomposition [6], advanced oxidation [7] and ion exchange [8]. However, a biological method is still considered as the preferable way of controlling phenol pollution since it is effective at low concentrations of phenol, cost-efficient. It does not produce secondary pollutants, as in the case of some physicochemical methods [1, 9]. The ability of some microorganisms to utilize phenol and other phenolic compounds is consider- 
ed as a tool for the disposal of toxic waste [10]. In fact, the attempt to use microorganisms to remove phenol and other organic environmental pollutants have been increasing in recent years. There are number of microorganisms that coexist in all-natural environments that can degrade organic compounds by producing intracellular or extracellular xenobiotics-degrading enzymes [11, 12, 13].

Many Pseudomonas species are used in biodegradation of phenol and phenolic compounds. For example, Pseudomonas sp. CF600, Pseudomonas sp. SA01 and Pseudomonas sp. strain JS150, which can degrade phenol by hydroxylat $[14,15,16]$. Other Pseudomonas species, such as Pseudomonas sp. strain ADP are able to degrades phenolic compounds like atrazine as a sole source of nitrogen [17].

Phenol biodegradation is affected by various factors such as temperature, $\mathrm{pH}$, nitrogen source, and salinity [12]. Optimization of these parameters is important in the scaling up of the microorganism for bioremediation. Response Surface Methodology (RSM) is a statistical tool used in the modeling and analyzing interest response when subjected to the influence of several independent factors. It is a more appropriate method for optimization than one factor at a time approach due to its time and materials effectiveness. Also, it indicates the presence of interactions between the various parameters $[18,19]$. The major components of RSM are; the selection of independent variables, the choice of experimental design, the statistical treatment, verification of the model fitness, obtaining the optimal values for each variable, and the validation of the results [18]. The design and optimization of biochemical processes require an investigational quantitative data. Therefore, this research is aimed to identify the phenol-degrading bacteria as well as to optimize the media and cultural conditions for phenol degradation and to test the effect of some heavy metals on the biodegradation process.

\section{Material and Methods \\ Isolation of phenol-degrading bacteria}

A total of 90 wastewater samples (freshwater) were collected in areas exposed to industrial activities within Malaysia including Sarawak and Peninsular Malaysia. Samples were collected between 2012 and 2013. The phenol-degrading bacterium AQ5-04 was isolated from a wastewater sample obtained at the GPS location $\mathrm{N}^{\circ} 3^{\circ} 01.658$ ', $\mathrm{E}^{\circ} 101^{\circ} 33.777^{\prime}$. This location receives water effluents from the pharmaceutical industry nearby. Four millilitre of wastewater sample was mixed with $40 \mathrm{~mL}$ of sterilized minimal salt medium (MSM) containing $0.5 \mathrm{~g} / \mathrm{L}$ phenol and incubated at $25^{\circ} \mathrm{C}$ on a shaking incubator at $150 \mathrm{rpm}$ for three days [20]. The cultures were streaked onto mineral medium agar plates supplemented with phenol and incubated at $25^{\circ} \mathrm{C}$ for three days. Isolates exhibiting distinct colonies were further isolated using five cycles of repeated subculturing into mineral medium agar plates supplemented with $0.5 \mathrm{~g} / \mathrm{L}$ phenol. Every single pure colony of isolates was inoculated in a $0.5 \mathrm{~g} / \mathrm{L}$ liquid phenol medium respectively and was daily monitored for phenol-degrading activity using the 4 aminoantipyrine colourimetric assay at $510 \mathrm{~nm}$. Meanwhile, the bacteria growth was measured using OD600 nm. The isolate that displays the highest phenol degradation (percentage) using aminoantipyrine (AAP) method was selected for further study [20].

\section{Molecular identification of the strain.}

AQ5-04 was identified through a molecular 16s rDNA gene sequence phylogenetic analysis. The genomic DNA was extracted using a commercial kit (GeneJet Genomic DNA purification kit, Thermoscientific, Lithuan) and amplified using the following PCR universal primers; forward: 5'AGA GTT TGA TCC TGG CTC AG-3' and reverse: 5'-TAC GGT TAC CTT GTT ACG ACT T3' [21]. The polymerase chain reaction (PCR) was done under the following conditions: 1 cycle of initial denaturation at $96^{\circ} \mathrm{C}$ for 4 minutes; 30 cycles of $94^{\circ} \mathrm{C}$ denaturing for $1 \mathrm{~min}$, annealing at $58^{\circ} \mathrm{C}$ for $1 \mathrm{~min}$, and $72^{\circ} \mathrm{C}$ extension for $1 \mathrm{~min}$ ) and a final extension at $72^{\circ} \mathrm{C}$ for 7 minutes. Phylogenetic tree analysis and evolutionary relationship of taxa: Twenty (20) 16s rDNA sequences of related Pseudomonas species were obtained from Genbank and aligned using Clustal W using PHYLIP.

\section{Optimization of physical and medium factor in- fluencing phenol degradation one factor at a time (OFAT)}

The optimization was done using $0.5 \mathrm{~g} / \mathrm{L}$ phenol as the sole source of carbon.

\section{Effects of temperature}

To evaluate the effect of temperature on phe- 
nol degradation by Pseudomonas sp. AQ5-04, the bacteria were grown in the MSM under various temperatures $\left(15\right.$ to $\left.45^{\circ} \mathrm{C}\right)$.

\section{Effects of $\mathrm{pH}$}

To determine the best and optimal $\mathrm{pH}$ bacterial growth and phenol degradation by Pseudomonas $s p$. AQ5-04, various pHs were used, with overlapping buffering systems, acetate buffer ( $\mathrm{pH} 4.0$ to 6.0), phosphate buffer (pH 6.0 to 7.5), and Tris$\mathrm{HCl}(\mathrm{pH} 7.0$ to 9.0) was used. The percentage of phenol degradation and bacterial growth was measured at the end of the incubation time.

\section{Effects of nitrogen sources.}

Various nitrogen sources were evaluated based on phenol degradation and bacterial growth by Pseudomonas sp. AQ5-04 to find the best nitrogen source. The nitrogen sources used for this study are ammonium sulphate, sodium nitrate, and nitrogen bicarbonate. Later, the best nitrogen source was optimised at concentrations of up to $0.8 \mathrm{~g} / \mathrm{L}$ in phenol-MSM to evaluate the best concentration for the growth and phenol degradation by Pseudomonas sp. AQ5-04.

\section{Effects of salinity.}

Sodium chloride was used at concentrations of up to $0.3 \mathrm{~g} / \mathrm{L}$ to evaluate the effect of salinity on phenol degradation and bacterial growth by Pseudomonas sp. AQ5- 04.

\section{Effect of different phenol concentrations.}

The effect of phenol concentrations on the bacterial growth and the percentage of phenol degradation were evaluated, various levels of phenol were used $(0.2$ to $2.4 \mathrm{~g} / \mathrm{L})$ as the sole source of carbon in the MSM.

\section{Effect of heavy metals.}

To examine the effect of heavy metals on phenol degradation and bacterial growth, ten different heavy metals were tested at various concentrations. The heavy metals involved are arsenic (As), cadmium (Cd), cobalt $(\mathrm{Co})$, copper $(\mathrm{Cu})$, chromium $(\mathrm{Cr})$, lead $(\mathrm{Pb})$, mercury $(\mathrm{Hg})$, nickel $(\mathrm{Ni})$, silver (Ag) and zinc (Zn).

\section{Statistical optimisation}

Central composite design (CDD) and response surface methodology (RSM) were used in this study. RSM is a statistical tool used in modelling and analyzing interest response when subjected to the influence of several independent factors. The main objective of using RSM in this study is to optimize phenol degradation (as a response). There are four major factors and interactions were analyzed and optimized by RSM. The selected major factors are temperature, $\mathrm{pH}$, salinity, and (NH4) $\mathrm{SO}_{4}$. This design consists of 30 experimental runs. All four independent factors were studied at five different levels: $-\alpha,-1,0,+1,+\alpha$. All experiments were carried out in triplicate and the average phenol degradation (response) in each run was recorded. The data obtained were fitted to a secondorder polynomial equation, which generates a model equation that relates $\mathrm{Y}$ to the independent factors. By using analysis of variance (ANOVA) tool in Expert-Design software version 6.0, p-values and confidence levels of the data obtained were calculated. Optimal values from linear and interactions of factors were estimated using 3D plots. The predicted values from RSM were validated by a set of experiments.

\section{Results and Discussions \\ Molecular identification of the strain}

Isolate AQ5-04 was identified using the 16S rDNA sequencing; the nucleotide sequence was compared to those on the NCBI Gene Bank database. rRNA sequence indicated a $99 \%$ similarity with Pseudomonas sp. The sequence was further deposited at the NCBI Gen bank and assigned an accession number of KT693288. The evolutionary history was inferred using the Neighbour-Joining method [22]. An optimal tree with the sum of branch length $=57.80900656$ was observed. The percentage of replicate trees in which the associated taxa clustered together in the bootstrap test (1000 replicates) was shown next to the branches [23]. The tree is drawn to scale with branch lengths of the same units as those of the evolutionary distances used to infer the phylogenetic tree. The evolutionary distances were computed using the Maximum Composite Likelihood method [24] in the units from the number of base substitutions per site. The analysis involved 17 nucleotide sequences. Codon positions included were $1^{\text {st }}+2^{\text {nd }}$ $+3^{\text {rd }}$. All positions containing gaps and missing data were eliminated. There was a total of 1377 positions in the final dataset. Evolutionary analyses were conducted in MEGA6 [25], as shown in Figure 1 . The analysis revealed that the bacterium 


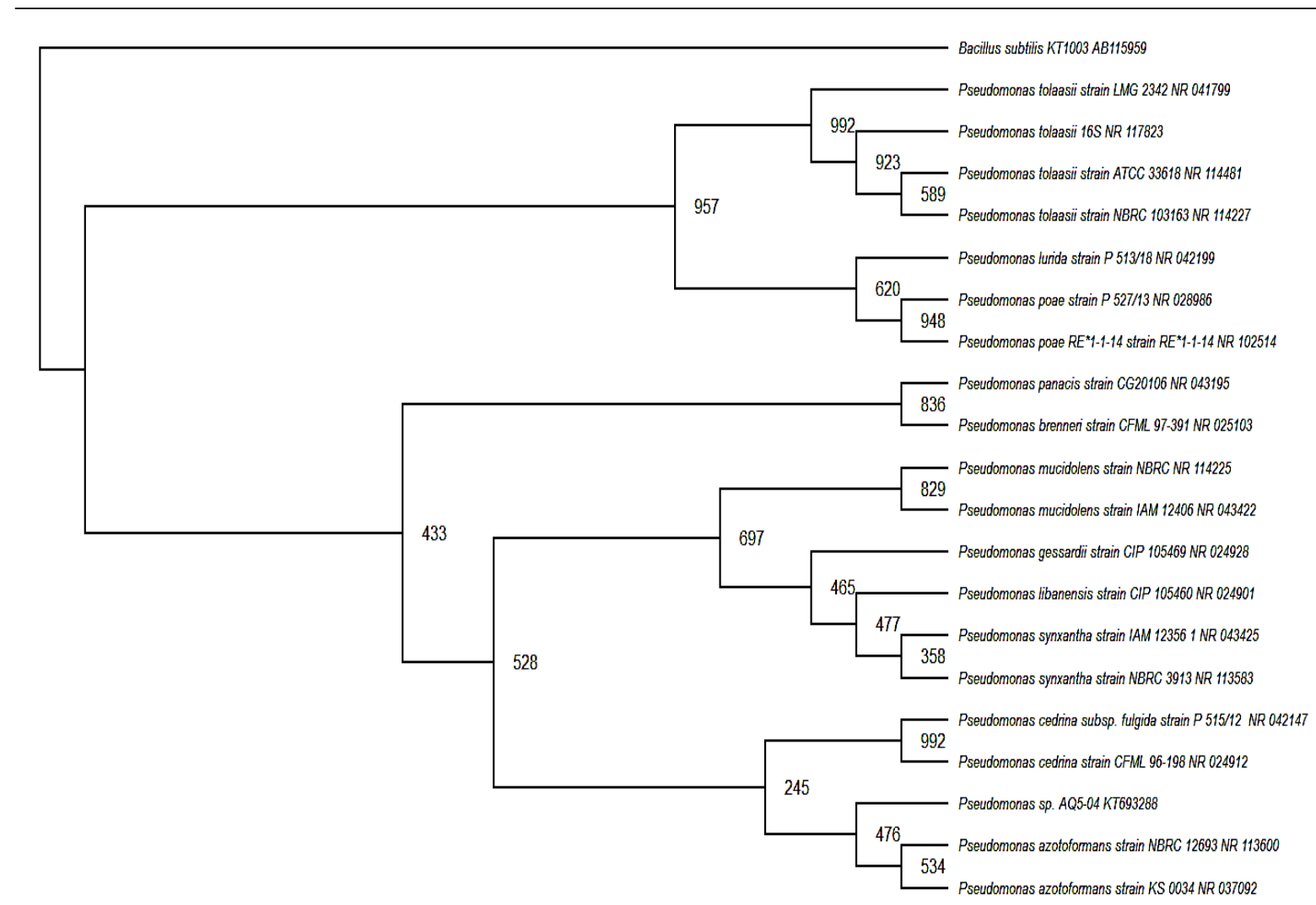

Figure 1. Neighbour-joining tree based on partial 16S RrRNA sequence demonstrating the phylogenetic relatedness of strain AQ5-04 within the Pseudomonas species and Bacillus subtilis strain KT1003 AB115959 was used as an outgroup

exhibited similarity with another Pseudomonas sp. The phylogenetic tree also exhibited that, the bacterium is associated with a clade that harbours other Pseudomonas sp. such as Pseudomonas azotoformans strain NBRC 12693 NR_113600, Pseudomonas synxantha strain NBRC 3913 NR 113583, Pseudomonas mucidolens strain NBRC NR_114225 and Pseudomonas cedrina strain CFML 96-198 NR_024912 as shown in Fig.1 The bacterium was therefore tentatively identified as Pseudomonas sp. AQ5-04.

\section{Effect of temperature}

Temperature is one of the factors affecting the growth and ability of a microorganism to be used in bioremediation. Studies on phenol degradation reported temperatures ranging from 10 to $55^{\circ} \mathrm{C}$ [26]. The optimum temperature for Pseudomonas pictorum and Pseudomonas sp. NBM11 was found to be $30^{\circ} \mathrm{C}[27,28]$. The results of this study revealed that Pseudomonas sp. Strain AQ5-04 sp. has an optimum temperature of $25^{\circ} \mathrm{C}$ to $35^{\circ} \mathrm{C}$ for both phenol degradation and bacterial growth (Figure 2a). There was no significant difference (p
$>0.05$ ) in phenol degradation percentage for the temperatures of 25,30 , and $35^{\circ} \mathrm{C}$. However, both the phenol degradation and bacterial growth declined at temperatures higher than $35^{\circ} \mathrm{C}$, which may be due to the inactivation or denaturation of the phenol degrading enzyme and some other proteins. Phenol degradation has been seen to be greatly affected by temperature [29]. Many studies have reported that the optimum temperature for phenol biodegradation is between $20^{\circ} \mathrm{C}$ to $35^{\circ} \mathrm{C}$ for mesophilic bacteria. Pseudomonas sp. strain AQ5-04 is a mesophilic bacterium; this further suggests the similarity between the obtained result and that of other researchers. The highest temperature limit for phenol degradation by mesophilic bacteria is $45^{\circ} \mathrm{C}$ [30], a thermophilic Bacillus sp. A2 was reported to grow in media containing phenol as the sole source of carbon at temperatures up to $70^{\circ} \mathrm{C}$ [31]. Phenol degradation efficiency of $\mathrm{A}$ cold-tolerant Arthrobacter sp. AG31 was reported.

\section{Effect of salinity}

Effect of salinity on the bacterial growth and to degrade phenol efficiently at $10^{\circ} \mathrm{C}$ [32]. 


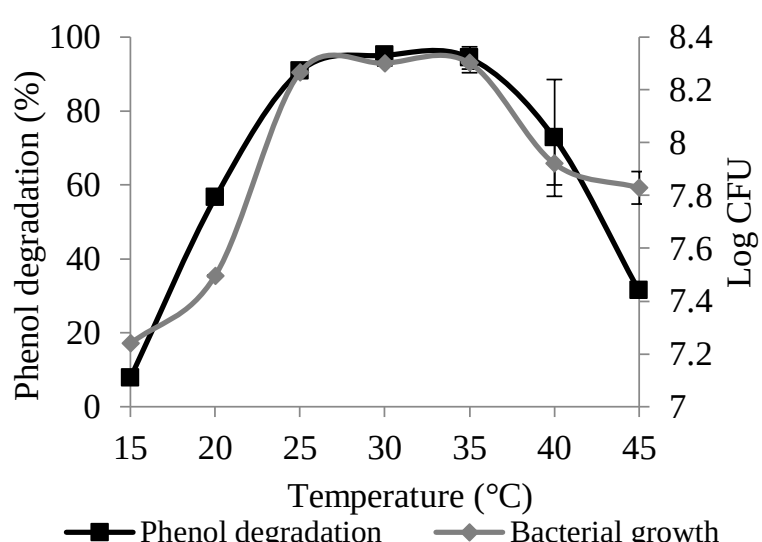

(a)

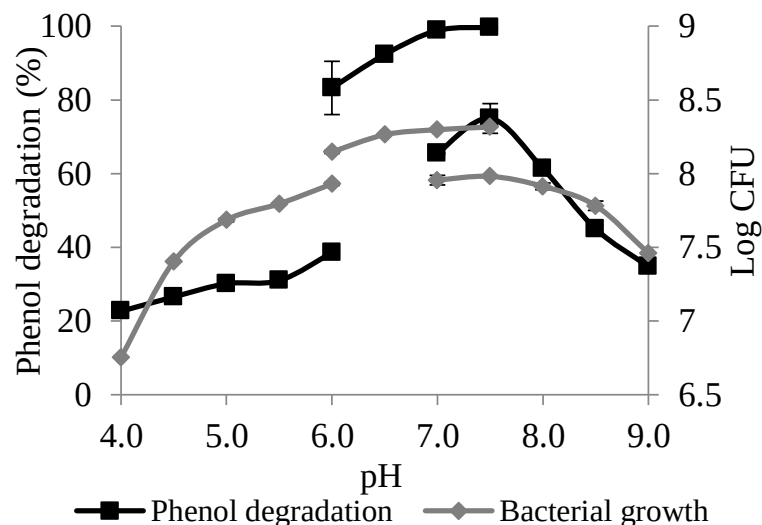

(b)

Figure 2. (a) Effect of temperature on phenol degradation and concentration and growth of Pseudomonas sp. AQ05-04 (b) Effect of pH on phenol degradation and concentration and growth of Pseudomonas sp. AQ05-04. Error bars indicates mean $\pm \mathrm{SEM}, \mathrm{n}=3$.

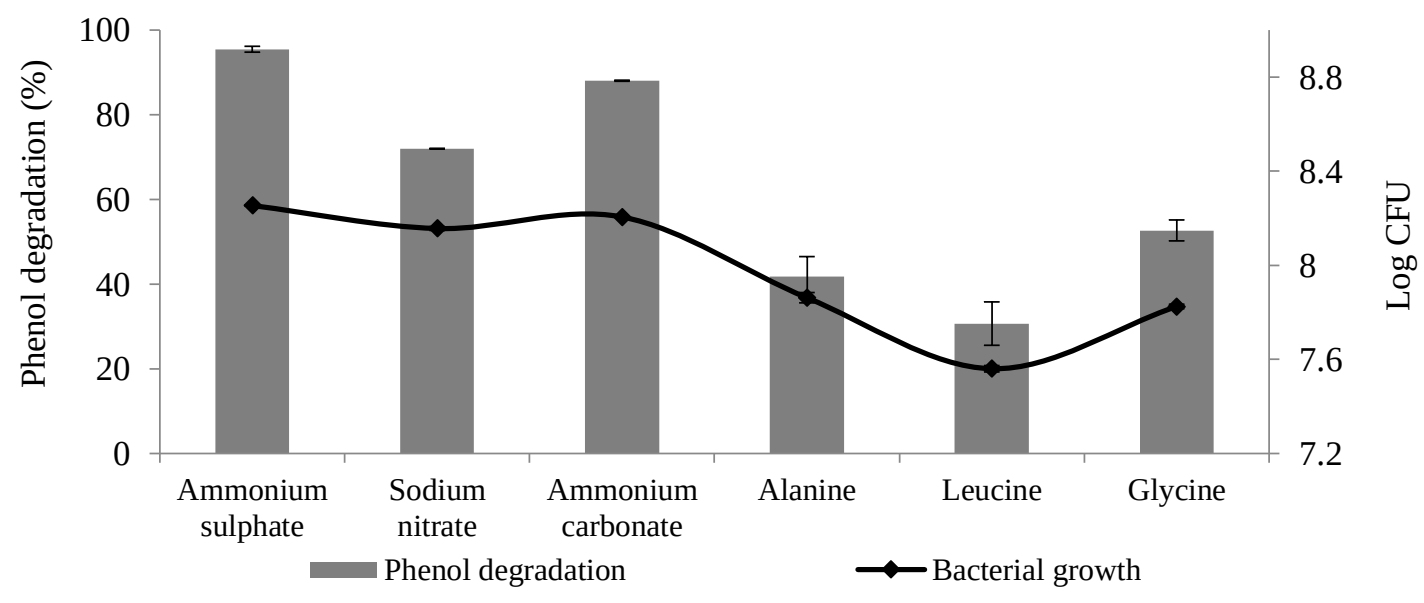

(a)

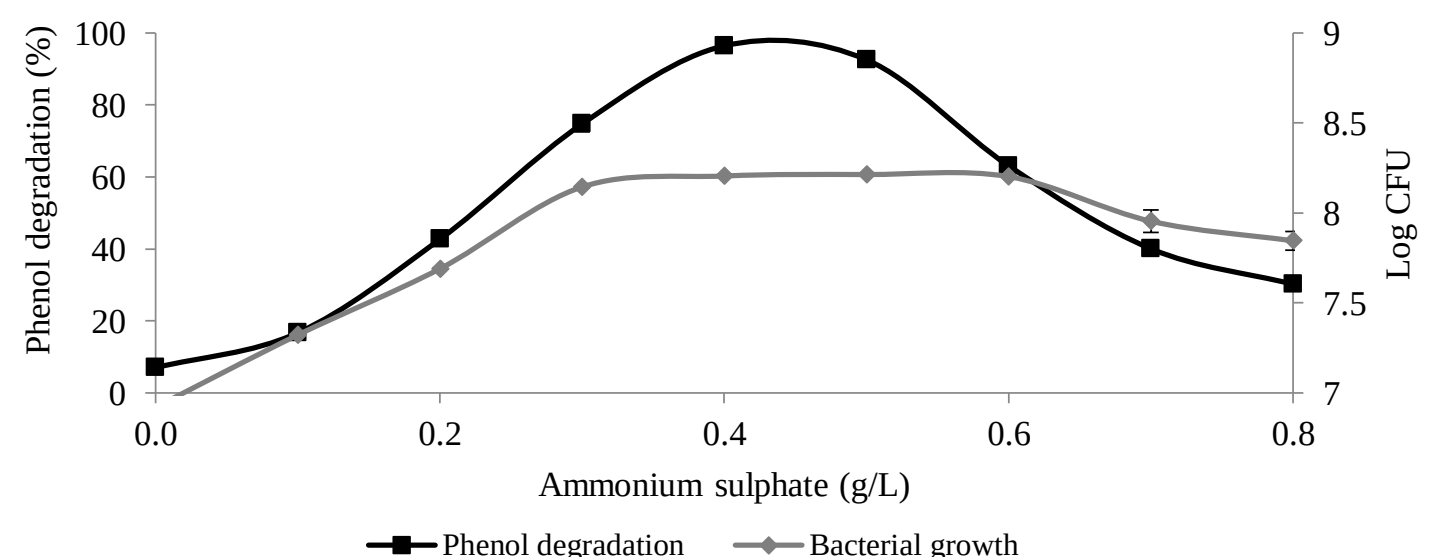

(b)

Figure 3. (a) Effect of nitrogen source on phenol degradation and concentration and growth of Pseudomonas sp. AQ05-04 (b) Effect of ammonium sulphate concentration on phenol degradation and concentration and growth of Pseudomonas sp. AQ05-04. Error bars indicates mean \pm SEM, n=3. 


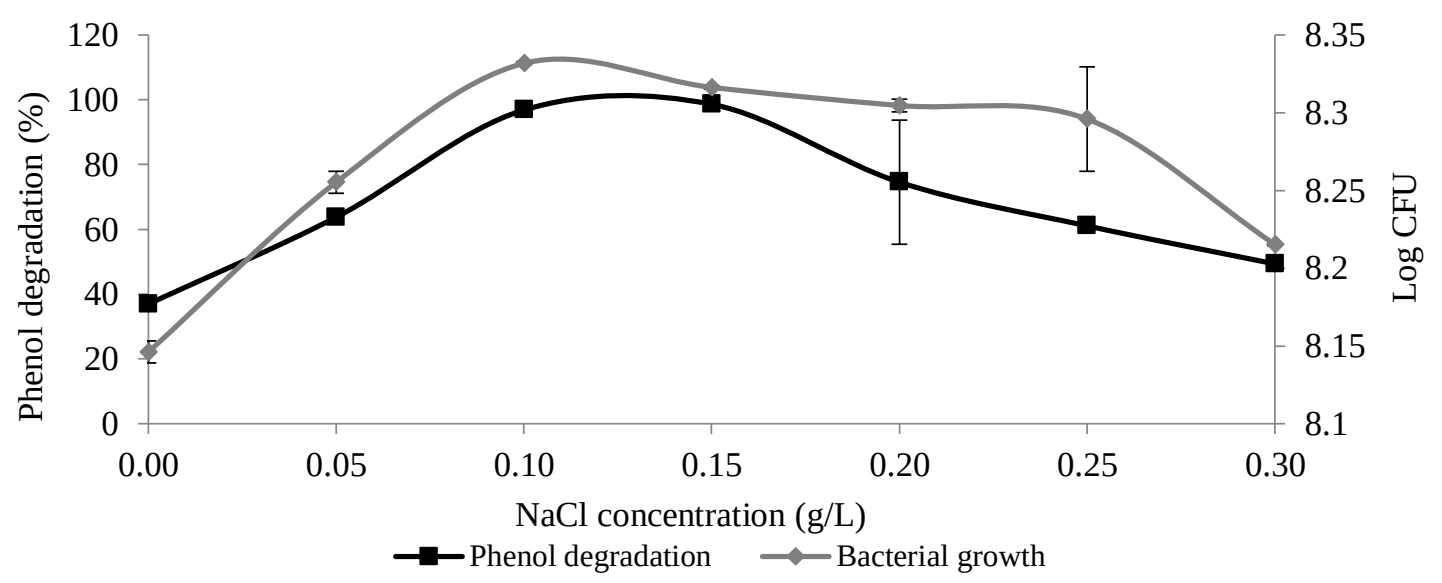

Figure 4. Effect of salinity on phenol degradation and concentration and growth of Pseudomonas sp. AQ05-04. Error bars indicates mean \pm SEM, $n=3$.

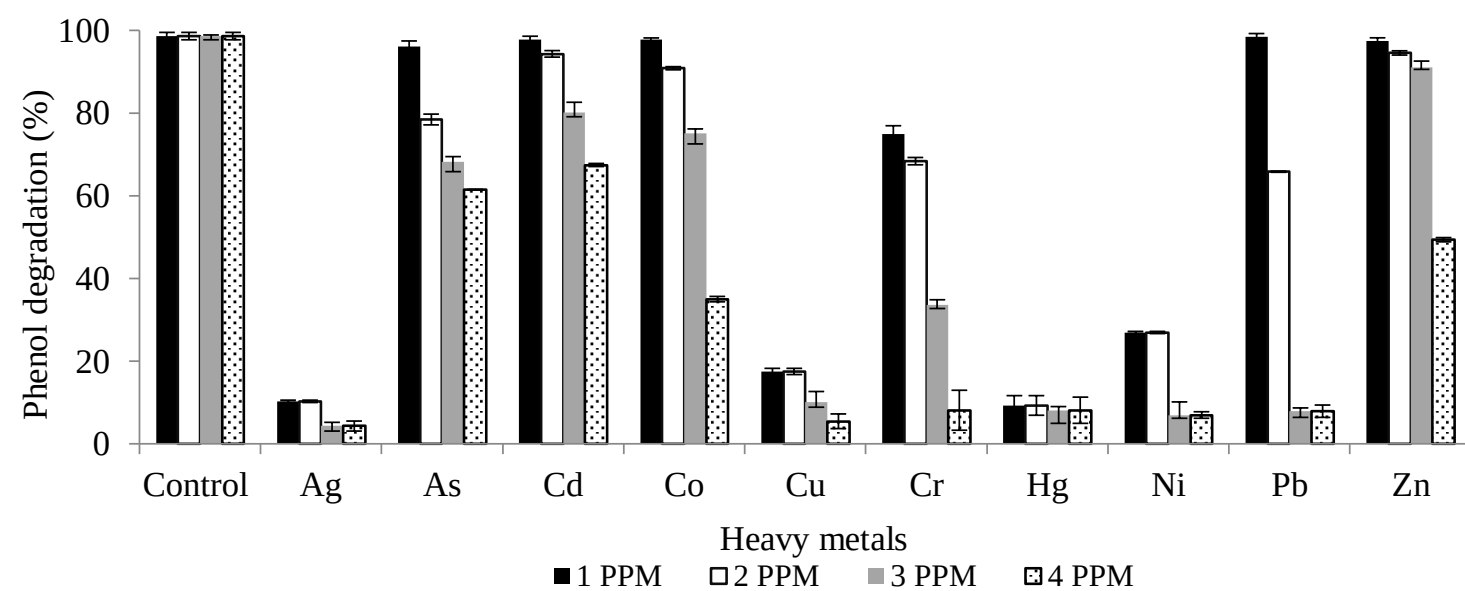

Figure 5. Effect of various heavy metals concentrations on the percentage phenol degradation by Pseudomonas sp. AQ05-04. Error bars indicates mean \pm SEM, $n=3$.

the phenol degradation was tested to determine whether or not isolate can be used to degrade phenol in the ocean or near coastal areas where there are reported cases of phenol pollution. The result revealed that sodium chloride between 0.1 and $0.15 \mathrm{~g} / \mathrm{L}$ was the best concentrations of sodium chloride in regards to growth and degradation. Meanwhile, high $\mathrm{NaCl}$ concentration displayed an inhibitory effect on the bacterial growth as well as phenol degradation, which may be due to an osmotic stress leading to the rupture of bacterial cells, thus inhibiting the growth and decreasing the degradation (Figure 4). The bacteria were unable to survive under high phenol concentrations. Phenol is a very toxic organic compound with an inhibitory effect on bacterial growth. Thus, there is no phenol degradation observed under high phenol concentrations. In most studies reported that bacterial growth is severely affected by a $\mathrm{NaCl}$ con- centration above $1.5 \%$. High salinity results in osmotic stress which hinder bacterial growth as while as biodegradation ability of the bacteria [26]. Some studies reported that Pseudomonas aeruginosa and $P$. fluorescens strains are able to grow in medium containing $1.5 \% \mathrm{NaCl}$ [39]. Certain bacteria from Amazon rainforest are tolerant high salinity. For example, Alicaligenes faecalis can withstand $56 \mathrm{~g} / \mathrm{L} \mathrm{NaCl}$, Candida tropicalis a yeast also from Amazon is reported to resist 150

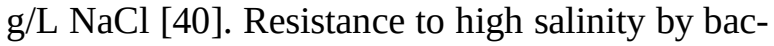
terial is an advantage for bioremediation of phenol and other pollutants at maritime and coastal areas [41]. Among the three isolates, Serratia sp. AQ503 has the advantage of growing well at $\mathrm{NaCl}$ higher than most reported concentrations [42].

\section{Effect of heavy metals}

Mercury (Hg) is considered the most toxic he- 
Table 3. Central composite design and it's experimental and predicted values of phenol degradation by Pseudomonas sp. AQ05-04

\begin{tabular}{|c|c|c|c|c|c|}
\hline Factor 1 & Factor 2 & Factor 3 & Factor 4 & \multicolumn{2}{|c|}{ Response } \\
\hline Temperature $\left({ }^{\circ} \mathrm{C}\right)$ & $\mathrm{pH}$ & Nitrogen source g/L & Salinity g/L & $\begin{array}{l}\text { Actual value } \\
\text { (and) }\end{array}$ & $\begin{array}{c}\text { Predicted value } \\
\text { (and) }\end{array}$ \\
\hline 30 & 7.5 & 1.10 & 0.15 & 93.9 & 93.61 \\
\hline 20 & 7.5 & 0.5 & 0.15 & 5.50 & 2.35 \\
\hline 30 & 10.5 & 0.5 & 0.15 & 33.20 & 34.74 \\
\hline 30 & 7.5 & 0.1 & 0.15 & 88.30 & 87.82 \\
\hline 30 & 4.5 & 0.5 & 0.15 & 82.00 & 79.70 \\
\hline 30 & 7.5 & 0.5 & 0.15 & 93.40 & 95.43 \\
\hline 40 & 7.5 & 0.5 & 0.15 & 64.80 & 67 \\
\hline 30 & 7.5 & 0.5 & 0.15 & 96.70 & 95.43 \\
\hline 30 & 7.5 & 0.5 & 0.25 & 57.66 & 58.90 \\
\hline 25 & 6.0 & 0.8 & 0.30 & 66.40 & 66.05 \\
\hline 35 & 9.0 & 0.2 & 0.30 & 49.20 & 46.76 \\
\hline 25 & 9.0 & 0.2 & 0.30 & 40.90 & 38.65 \\
\hline 25 & 6.0 & 0.2 & 0.00 & 43.90 & 42.86 \\
\hline 35 & 9.6 & 0.8 & 0.30 & 55.70 & 54.03 \\
\hline 25 & 9.6 & 0.8 & 0.30 & 44.30 & 46.76 \\
\hline 30 & 7.5 & 0.5 & 0.15 & 93.01 & 95.43 \\
\hline 35 & 6.0 & 0.2 & 0.00 & 99.40 & 100.42 \\
\hline 35 & 9.0 & 0.8 & 0.00 & 71.80 & 71.39 \\
\hline 25 & 6.0 & 0.8 & 0.00 & 33.87 & 40.05 \\
\hline 30 & 7.5 & 0.5 & 0.15 & 95.20 & 95.43 \\
\hline 25 & 9.0 & 0.8 & 0.00 & 86.92 & 88.32 \\
\hline 35 & 9.0 & 0.2 & 0.00 & 77.12 & 74.76 \\
\hline 35 & 6.0 & 0.8 & 0.00 & 98.57 & 98.11 \\
\hline 30 & 7.5 & 0.5 & 0.45 & 70.10 & 69.50 \\
\hline 30 & 7.5 & 0.5 & 0.15 & 73.00 & 72.83 \\
\hline 35 & 6.0 & 0.8 & 0.30 & 96.70 & 97.15 \\
\hline 25 & 6.0 & 0.2 & 0.30 & 53.00 & 56.89 \\
\hline 30 & 7.5 & 0.5 & 0.15 & 96.10 & 95.43 \\
\hline 25 & 9.0 & 0.2 & 0.00 & 38.00 & 41.03 \\
\hline 35 & 6.0 & 0.2 & 0.30 & 92.90 & 91.81 \\
\hline
\end{tabular}

avy metal, while $\mathrm{Pb}$ is relatively toxic to a living organism [43]. Also, a small amount of $\mathrm{Zn}$ and $\mathrm{Cu}$ are essential for basic metabolic activities in a microorganism but are toxic to the bacteria in high concentrations. Other metals like $\mathrm{Hg}, \mathrm{Pb}, \mathrm{Cd}$ and $\mathrm{Cr}$ have no known significant role in bacterial growth and development as they are known to be toxic to living organisms even at low concentration [44]. Strain AQ5-04 is effective in biodegrading phenol even with the presence of heavy metals. $\mathrm{Hg}, \mathrm{Cu}, \mathrm{Ag}$, and $\mathrm{Ni}$ are the toxic heavy metals related to this strain. Even at the concentration of 1 $\mathrm{ppm}$, the degradation percentages were found to be $9.2 \%, 10 \%, 17 \%$ and $26 \%$, respectively. This sug- gests the inhibitory effects contributed by these heavy metals on phenol degradation even at $1 \mathrm{ppm}$ (Figure 5), which might be due to their ability to inhibit several key enzymes in biodegradation processes or because of their toxic property to some essential proteins and some cellular components in the bacterial biological systems [45]. Likewise, heavy metals, As, Cd, Co, Pb, and $\mathrm{Zn}$ show low effects at lower concentrations, but as the concentrations increases, they displayed strong inhibitory effects on the degradation rate. At 3 and $4 \mathrm{ppm}$, there is a decline in the degradation rate for the six heavy metals that have no significant inhibitory effect at lower concentrations; Nevertheless, in the 


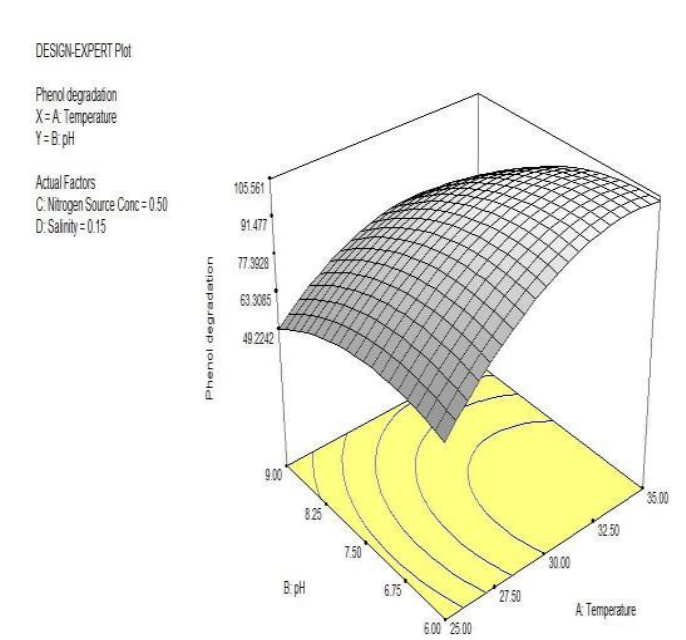

(a)

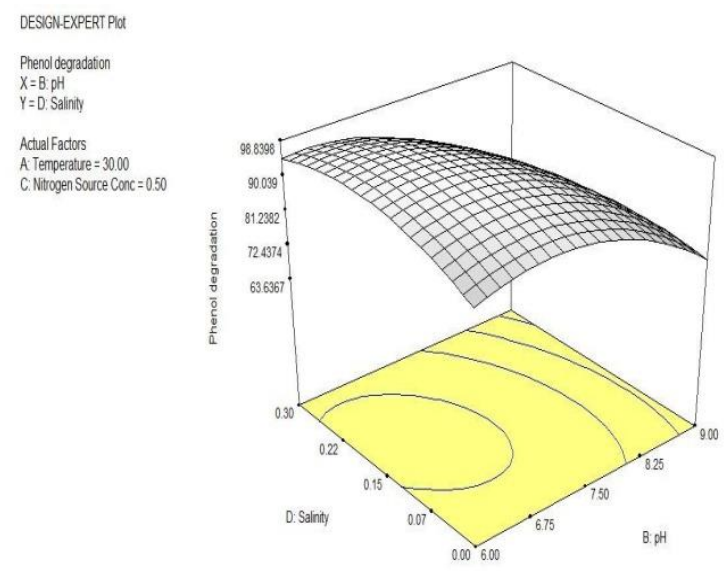

(c)
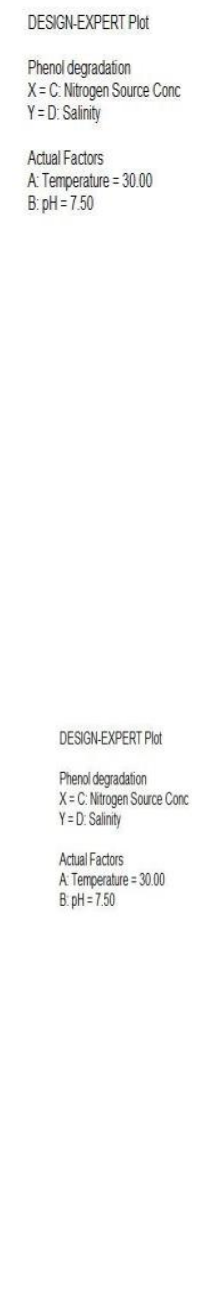

Figure 6. 3-D plots of phenol degradation for surface optimization a $\mathrm{pH}$ versus temperature; $\mathrm{b}$ salinity versus ammonium sulphate concentration ammonium sulphate concentration versus Temperature; c salinity versus temperature; $d$ ammonium sulphate concentration versus $\mathrm{pH}$;

presence of As and Cd at 3 and 4 ppm at degradation rate was found to be more than more than $60 \%$ as shown in Figure 5. Various isolates have been reported to tolerance phenols with some heavy metals, but this isolate can degrade phenol contaminated with up to $3 \mathrm{ppm}$ of some known toxic heavy metals but inhibited by Hg and Ag. Previous studies indicated that Hg inhibits phenol degradation by microorganisms such as Pseudomonas aeruginosa and Pseudomonas fluorescence [46], Aureobasidium pullulans [47], Bacillus brevis [48], Alcaligene sp. [49] and Sulfobacillusacidophilus [50]. Ag also has been reported to inhibit phenol degradation and as well as bacterial growth by Rhodococcus AQ5NOL1 [34].

\section{Statistical optimization}

The results from RSM revealed that the model is significant $(<0.05)$ with the F-value of 196.57 (Table 1 ) where there is only a $0.01 \%$ chance that a "Model F-Value" this large could occur due to noise. Besides, the lack of fit for the model is not significant (>0.05). Meanwhile, Values of "Prob $>\mathrm{F}^{\prime}$ less than 0.0500 indicated that the model terms are significant [51].

In this case, $A, C, D, A^{2}, B^{2}, D^{2}, A C, B C, C D$ are the significant model terms. On the other hand, values greater than 0.1000 indicated insignificant model terms (Table 1). It showed that the response (phenol degradation) depends on the product and quadratic product of $\mathrm{X}_{\mathrm{a}}, \mathrm{X}_{\mathrm{b}}, \mathrm{X}_{\mathrm{c}}$, and $\mathrm{X}_{\mathrm{d}}$. Lower estimation of 3.59\% coefficient of variance (CV) additionally portrays the unwavering high quality of trial information [52]. Table 2 illustrates the model coefficient and their statistical significance by multiple regression for percentage phenol degra- 
tion. The four variables (temperature, $\mathrm{pH}$, ammonium sulphate concentration and salinity) influencing phenol degradation as reported by [53]. Table 3 illustrated the predicted responses and also the actual responses.

Analysis of 3D interactive plots presented that there is an interaction between temperature (A) and $\mathrm{pH}(\mathrm{B})$, temperature and salinity (D), $\mathrm{PH}$ and salinity, as well as between ammonium sulphate concentration and salinity (Figure 6a to 6d), which further displayed a higher phenol degradation achieved at the temperature of $30^{\circ} \mathrm{C}, \mathrm{pH} 7.50 .5$ $\mathrm{g} / \mathrm{L}$ ammonium sulphate and $0.15 \mathrm{~g} / \mathrm{L}$ sodium chloride. The predicted data from the model was experimentally verified. A modified phenol basal media was formulated with predicted model values and percentage degradation was then detected. The results showed 99\% phenol degradation in an incubation period of $36 \mathrm{~h}$. RSM has reported being used for optimisation in phenol biodegradation, $100 \%$ phenol degradation was achieved using the RSM optimised parameters by Rhodococcus sp. NAM 81 [12]. Alcaligenes faecalis was able to degrade $100 \%$ of $2100 \mathrm{mg} / \mathrm{L}$ phenol using RSM optimised conditions [54]. P. Aeruginosa (MTCC 7814) remove $83.86 \%$ phenol using RSM validation experiment [37].

\section{Conclusion}

Pseudomonas sp. strain AQ5-04 has been identified and optimized for phenol biodegradation. The study reveals that the strain grows and degrades best when ammonium sulphate is used as a source of nitrogen sources. A pH value of 7 was identified as the best $\mathrm{pH}$ for phenol degradation by these bacteria. Also, the optimum temperature was found at $30^{\circ} \mathrm{C}$, which is within the average range of temperature in Malaysia. The bacterium was able to degrade up to $98 \%$ of $5 \mathrm{mg} / \mathrm{L}$ phenol in mineral salt media. It has also degraded up to $70 \%$ of $8 \mathrm{mg} / \mathrm{L}$ phenol. The optimum condition for phenol remediation was further revealed with the help of response surface methodology. The optimal conditions were obtained from this model using the factors responsible for phenol degradation in central composite design. The optimum values used for temperature, $\mathrm{pH}$, ammonium sulphate and salinity for both the OFAT and RSM have correlated with the only $\mathrm{pH}$ displayed the slighted difference of 7.0 for OFAT and 7.5 for RSM. This shows the closest optimum conditions for both methods. The strain is also resistance to some heavy metals usually found in polluted environments together with phenol. Therefore, it can be clearly stated that Pseudomonas sp. strain AQ5-04 is the potential candidate for phenol bioremediation and further studies in the field of bioremediation.

\section{References}

1. Hank D, Saidani N, Namane A, Hellal A (2010) Batch Phenol Biodegradation Study and Application of Factorial Experimental Design. Journal of Engineering Science and Technology Review 3 (1): 123-127.

2. Hirooka T, Akiyama Y, Tsuji N et al. (2003) Removal of Hazardous Phenols by Microalgae under Photoautotrophic Conditions. Journal of Bioscience and Bioengineering 95 (2): 200-203. doi: 10.1263/jbb.95.200.

3. Afilah Abd G, Shukor MY, Khalil KA et al. (2014) Phenol and Its Toxicity. Journal of Environmental Microbiology and Toxicology 2 (1): 11-24.

4. Bilge E, Zagorevski D, Zhu G et al. (2009) Enzymatic Polymerisation of Phenol in Room Temperature Ionic Liquid. Journal of Molecular Catalysis B: Enzymatic 59 (3): 177-84.

5. Abdelwahab O, Amin NK, El-Ashtoukhy ESZ (2009) Electrochemical Removal of Phenol from Oil Refinery Wastewater. Journal of Hazardous Materials 163 (2-3): 711-716. doi: 10.1016/j.jhazmat.2008.07.016.

6. Akbal F, Onar AN (2003) Photocatalytic Degradation of Phenol. Environmental Monitoring and Assessment 83 (3): 295-302. doi: 10.1023/A:1022666322436.

7. Liotta LF, Gruttadauria M, Di Carlo G et al. (2009). Heterogeneous Catalytic Degradation of Phenolic Substrates: Catalysts Activity. Journal of Hazardous Materials 162 (2-3): 588-606. doi: 10.1016/j.jhazmat.2008.05.115.

8. Alkaram UF, Mukhlis AA, Al-Dujaili AH (2009) The Removal of Phenol from Aqueous Solutions by Adsorption Using Surfactant-Modified Bentonite and Kaolinite. Journal of Hazardous Materials 169 (1-3): 324-32.

9. Kulkarni, Sunil J, Kaware JP (2013) Review on Research for Removal of Phenol from Wastewater. International Journal of Scientific and Research Publications 3 (4): 15.

10. Agarry SE, Solomon BO, Layokun SK (2008) Kinetics of Batch Microbial Degradation of Phenols by Indigenous Binary Mixed Culture of Pseudomonas Aeruginosa and Pseudomonas Fluorescens. International Journal of Environmental Science and Technology 7 (1/14): 24172423. doi: 10.1504/IJEP.2010.035922.

11. Nair CI, Jayachandran K, Shashidhar S (2008) Biodegra- 
dation of phenol. African journal of biotechnology 7 (25).

12. Norazah MN, Ahmad SA, Shukor MY et al. (2016) Statistical Optimisation for Improvement of Phenol Degradation by Rhodococcus sp. NAM 81. Journal of Environmental Biology 37 (May): 355-360

13. Ahmad SA, Shamaan NA, Arif NM et al. (2012). Enhanced phenol degradation by immobilized Acinetobacter sp. strain AQ5NOL 1. World Journal of Microbiology and Biotechnology 28 (1): 347-352.

14. Haigler BE, Pettigrew CA, Spain JC (1992) Biodegradation of mixtures of substituted benzenes by Pseudomonas sp. strain JS150. Applied and Environmental Microbiology 58 (7): 2237 - 2244.

15. Powlowski J, Shingler V (1994) Genetics and biochemistry of phenol degradation by Pseudomonas sp. CF600. Biodegradation 5 (3-4): 219 - 236.

16. Shourian M, Noghabi KA, Zahiri HS et al. (2009) Efficient Phenol Degradation by a Newly Characterized Pseudomonas Sp. SA01 Isolated from Pharmaceutical Wastewaters. Desalination 246 (1-3): 577-94.

17. Neumann G, Teras R, Monson L et al. (2004) Simultaneous degradation of atrazine and phenol by Pseudomonas sp. strain ADP: effects of toxicity and adaptation. Applied and Environmental Microbiology 70 (4): 1907 1912.

18. Bezerra MA, Santelli RE, Oliveira EP et al. (2008). Response surface methodology (RSM) as a tool for optimi zation in analytical chemistry. Talanta 76 (5): 965 - 977.

19. Zhou J, Yu X, Ding C et al. (2011). Optimisation of phenol degradation by Candida tropicalis Z-04 using Plackett-Burman design and response surface methodology. Journal of Environmental Sciences 23: 22-30.

20. Bai J, Wen JP, Li HM, Jiang Y (2007) Kinetic modeling of growth and biodegradation of phenol and m-cresol using Alcaligenes faecalis. Process Biochemistry 42 (4): 510 - 517.

21. Karamba KI, Shukor MY, Syed MA et al. (2015) Isolation, Screening and Characterisation of Cyanide-Degrading Serratia Marcescens Strain AQ07. Journal of Chemical and Pharmaceutical Sciences 8 (2): 401-406

22. Saitou N, Nei M (1987) The Neighbor-Joining Method: A New Method for Reconstructing Phylogenetic Trees. Molecular Biology and Evolution 4: 406 - 425.

23. Felsentein J (1985) Confidence Limits on Phylogenies: An Approach Using the Bootstrap. Evolution 39 (4): 783-91.

24. Tamura K, Nei M, Kumar S (2004) Prospects for Inferring Very Large Phylogenies by Using the NeighborJoining Method. Proceedings of the National Academy of Sciences of the United States of America 101 (30):
11030 - 11035. doi: 10.1073/pnas.0404206101.

25. Tamura K, Stecher G, Peterson D et al. (2013) MEGA6: Molecular Evolutionary Genetics Analysis Version 6.0. Molecular Biology and Evolution 30 (12): 2725 - 2729. doi: 10.1093/molbev/mst197.

26. Suhaila YN, Rosfarizan M, Ahmad SA et al. (2013). Nutrients and Culture Conditions Requirements for the Degradation of Phenol by Rhodococcus UKMP-5M. Journal of Environmental Biology 34 (3): 635-643.

27. Annadurai G, Ling LY, Lee J (2007) Biodegradation of phenol by Pseudomonas pictorum on immobilized with chitin. African Journal of Biotechnology 6 (3).

28. Mohanty SS, Jena HM (2017) Biodegradation of phenol by free and immobilized cells of a novel Pseudomonas sp. NBM11. Brazilian Journal of Chemical Engineering, 34 (1): 75-84.

29. Khleifat KM (2006) Biodegradation of Phenol by Ewingella Americana: Effect of Carbon Starvation and Some Growth Conditions. Process Biochemistry 41 (9): 2010-2016. doi: 10.1016/j.procbio.2006.04.015.

30. Levén L, Schnu A (2007) Effect of Process Temperature on Bacterial and Archaeal Communities in Two Methanogenic Bioreactors Treating Benzoates and Phthalates under Methanogenic Conditions. International Biodeterioration \& Biodegradation 2005: 153-160. doi: 10.1016/j.ibiod.2004.09.004.

31. Mutzel A, Reinscheid UM, Antranikian G, MuÈller R (1996) Isolation and Characterization of a Thermophilic Bacillus Strain, That Degrades Phenol and Cresols as Sole Carbon Source at $70^{\circ} \mathrm{C}$. Applied Microbiology and Biotechnology: 593-596.

32. Margesin R, Bergauer P, Gander S (2004) Degradation of Phenol and Toxicity of Phenolic Compounds: A Comparison of Cold-Tolerant Arthrobacter sp . and Mesophilic Pseudomonas Putida. Extremophiles, 201207. doi: 10.1007/s00792-004-0378-3.

33. Louise AD, Bååth E (2008) The Use of Leucine Incorporation to Determine the Toxicity of Phenols to Bacterial Communities Extracted from Soil. Applied Soil Ecology 38 (1): 34-41. doi: 10.1016/j.apsoil.2007.08.008.

34. Arif NM, Ahmad SA, Syed MA, Shukor MY (2013) Isolation and Characterization of a Phenol-Degrading Rhodococcus Sp. Strain AQ5NOL 2 KCTC 11961BP. Journal of Basic Microbiology 53 (1): 9-19. doi: 10.1002/jobm.201100120.

35. Veenagayathri K, Vasudevan N (2010) Effect of pH, Nitrogen Sources and Salts on the Degradation of Phenol by the Bacterial Consortium under Saline Conditions.International Journal of Biochemistry and Biotechnology 6: 783-971.

36. Alshehrei F (2017). Effect of physicochemical factors on 
the biodegradation of phenol by Pseudomonas putida ATCC 12842 and Pseudomonas fluorescens ATCC 948. African Journal of Biotechnology 16 (39):1962-1968 doi: 10.5897/AJB2017.16172.

37. Chandana L,Sridevi V, Narasimha Rao M, Swamy A (2011) Optimization of Phenol Degradation from Pseudomonas Aeruginosa (NCIM 2074) Using Response Surface Methodology. International Journal of Research in Pharmacy and Chemistry 1 (4): 925-935.

38. Ghaima KK, Rahal BS, Mohamed MM (2017) Biodegradation of phenol by Pseudomonas aeruginosa isolated from soil contaminated with diesel fuel. Bioscience Research 14 (4): 713-720.

39. Deshwal VK, Kumar P (2013) Effect of salinity on growth and PGPR activity of Pseudomonads. Journal of Academia and Industrial Research 2 (6): 353-356.

40. Bastos AER, Tornisielo VL, Nozawa SR et al. (2000) Phenol Metabolism by Two Microorganisms Isolated from Amazonian Forest Soil Samples. Industrial Microbiology \& Biotechnology 24 (March): 403-9.

41. Durán N, Esposito E (2000) Potential Applications of Oxidative Enzymes and Phenoloxidase-like Compounds in Wastewater and Soil Treatment: A Review. Applied Catalysis B: Environmental 28 (2): 83-99. doi: doi: 10.1016/S0926-3373(00)00168-5.

42. Bukowska B, Kowalska S (2003) The Presence and Toxicity of Phenol Derivatives-their Effect on Human Erythrocytes. Current Topics in Biophysics 27(1-2): 4351.

43. Alzubaidy SK (2012) The Resistance of Locally Isolated Serratia Marcescens to Heavy Metals Chlorides and Optimization of Some Environmental Factors. Journal of Environmental and Occupational Science 1 (1): 37-42.

44. Sethuraman P, Dharmondira KM (2011) Application of Bacteria to Remove Ni (II) Irons from Aqueous Solution. European Journal of Scientific Research 52 (3): 345 358.

45. Wagner-Dobler I, Lunsdorf $\mathrm{H}$, Lubbehusen $\mathrm{T}$ et al. (2000) Structure and Species Composition of MercuryReducing Biofilms. Applied Environmental Microbiology 66: 4559 - 4569 .
46. Oboirien BO, Ojumu TV, Ogunkunle OA et al. (2005) Substrate Inhibition Kinetics of Phenol Degradation by Pseudomonas Aeruginosa and Pseudomonas Fluorescence. Biotechnology 4 (1): 56-61.

47. Dos Santos VL, Monteiro AS, Braga DT, Santoro MM (2009) Phenol Degradation by Aureobasidium Pullulans FE13 Isolated from Industrial Effluents. Journal of Hazardous Materials 161 (2-3): 1413-1420. doi: 10.1016/j.jhazmat.2008.04.112.

48. Arutchelvan V, Kanakasabai V, Elangovan R et al. (2006) Kinetics of High Strength Phenol Degradation Using Bacillus Brevis. Journal of Hazardous Materials 129 (1-3): 216-222. doi: 10.1016/j.jhazmat.2005.08.040.

49. Essam T, Amin MA, El Tayeb O et al. (2010) Kinetics and Metabolic Versatility of Highly Tolerant Phenol Degrading Alcaligenes Strain TW1. Journal of Hazardous Materials 173 (1-3): 783-788. doi: 10.1016/j.jhazmat.2009.09.006.

50. Zhou W, Guo W, Zhou H, Chen X (2016) Phenol Degradation by Sulfobacillus Acidophilus TPY via the MetaPathway. Microbiological Research 190: 37-45. doi: 10.1016/j.micres.2016.05.005.

51. Aghaie E, Pazouki M, Hosseini MR et al. (2009) Response Surface Methodology (RSM) Analysis of Organic Acid Production for Kaolin Beneficiation by Aspergillus Niger. Chemical Engineering Journal 147 (23): 245-51. doi: 10.1016/j.cej.2008.07.008.

52. Box GEP, Behnken DW (1960) Some new three level designs for the study of quantitative variables. Technometrics 2: 455-475.

53. Ghanem KM, Al-Garni SM, Al-Shehri N (2009) Statistical Optimization of Cultural Conditions by Response Surface Methodology for Phenol Degradation by a Novel Aspergillus Flavus Isolate. African Journal of Biotechnology 8 (15): 3576-83. doi: 10.5897/AJB09.413.

54. Mandal S, Bhunia B, Kumar A et al. (2013) A Statistical Approach for Optimization of Media Components for Phenol Degradation by Alcaligenes Faecalis Using Plackett-Burman and Response Surface Methodology. Desalination and Water Treatment 51 (31-33): 60586069. doi: 10.1080/19443994.2013.769746 
This page is intentionally left blank 